\title{
Antioxidant and Anti-Apoptotic Activities of Phytochemically Validated Fruit Extract of Solanum xanthocarpum in Primary Chondrocytes
}

\author{
Neelam Shivnath ${ }^{1 *}$, Vineeta Rawat ${ }^{1}$, Sahabjada ${ }^{1,2}$, Asif Jafri ${ }^{1}$, Juhi Rais ${ }^{1}$ Habiba Khan ${ }^{1}$, and Md. Arshad ${ }^{1 *}$ \\ 'Molecular Endocrinology Lab, Department of Zoology, University of Lucknow, Lucknow - 226007, Uttar Pradesh, India; \\ neelamshivnath@yahoo.co.in; arshadm123@rediffmail.com \\ 2Department of Biochemistry, Era's Lucknow Medical College and Hospital, Lucknow - 226003, Uttar Pradesh, India
}

\begin{abstract}
The chondrocyte death may contribute in progression of osteoarthritis (OA). Solanum xanthocarpum (Family: Solanaceae) fruits were known for antioxidant activity. This study demonstrates that the phytochemically validated Solanum xanthocarpum fruits (SXF) extract has inhibitory activities on nitric oxide (NO) induced cell death and ROS formation in primary cultured chondrocytes. Chondrocyte death was induced by $1.5 \mathrm{mM}$ of Sodium Nitroprusside (SNP). The Cell viability was measured by MTT assay and nuclear changes were observed by DAPI and Hoechst-PI. Antioxidant activity of SXF was demonstrated in $\mathrm{H}_{2} \mathrm{O}_{2}$ induced ROS generation in chondrocytes. Indomethacin (IM) $(25 \mu \mathrm{M})$, a NSAID was taken as positive control. Phytochemical analysis revealed the presence of flavonoids, anthraquinone glycosides, steroids, alkaloids, terpenoids and tannins. SXF significantly reduces the cell death induced by SNP in a dose dependent manner. The fluorescent photomicrograph of DAPI, Hoechst-PI and ROS also revealed the decreased rate of apoptosis in a dose-dependent manner. This study suggests that SXF shows anti-apoptotic and antioxidant activity in chondrocytes.
\end{abstract}

Keywords: Apoptosis, Chondrocytes, Non-Steroidal Anti-Inflammatory Drugs (NSAIDs), Osteoarthritis, Phytochemicals

\section{Introduction}

Osteoarthritis is associated with the breakdown and ultimate loss of articular cartilage of joints ${ }^{1}$ and is commonly occurs among the elderly population in the world 2 . Several etiological risk factors like age, gender, trauma, overuse, genetics and obesity are associated with pathophysiologic processes that contribute disease progression ${ }^{3}$. In the pathological condition the cells of articular joints are subjected to complex environmental control. In addition to various cytokines, growth factors, and mechanical stimuli, reactive oxygen specie (ROS) contributes in pathological condition. Therefore, a functional change in chondrocytes of articular cartilage is related to the progression of $\mathrm{OA}^{4}$. Overproduction of oxidants (reactive oxygen species and reactive nitrogen species) in the human body is responsible for the pathogenesis of some diseases. Nitric Oxide (NO) and superoxide anion $\left(\mathrm{O}_{2}^{-}\right)$are the main ROS produced by chondrocytes ${ }^{5}$. ROS like superoxide anion $\left(\mathrm{O}_{2}{ }^{-}\right)$, Hydrogen Peroxide $\left(\mathrm{H}_{2} \mathrm{O}_{2}\right)$, and hydroxyl radicals $\left(\mathrm{OH}^{-}\right)$are the byproduct of aerobic metabolism ${ }^{6}$ and are associated with principal oxidative stress molecules. The enzyme complex $\mathrm{NADPH}$ catalyzes the reduction of molecular oxygen to superoxide anion radicals 4 . The production of NO is stimulated by various cytokines including interleukin (IL)- $\beta$, tumor necrosis factor (TNF)- $\alpha$, interferon (IFN) $-\gamma$ and lipopolysaccharides (LPS), and inhibited by Transforming growth factors (TGF)- $\beta$, IL-4, IL-10 and IL-13-9. It is believed that NO is an important mediator of dedifferentiation and apoptosis of chondrocytes in arthritic cartilage ${ }^{10}$.

Non-steroidal anti-inflammatory drugs are commonly used drugs in the entire world for the treatment of osteoarthritis. Long-term use of these NSAIDs leads to significant side effects on liver, stomach, gastrointestinal tract and heart ${ }^{\underline{11}}$. Therefore it becomes essential to explore alternative medi-

${ }^{*}$ Author for correspondence 
cine derived from herbal plants with a potential drug that is effective in terms of both efficacy and safety. Medicinal plants provide a significant source of chemical compounds that have a great importance on the health of individual and community. There is wide diversity of chemical compounds that have been isolated from plant especially secondary metabolites that were shown to have anti-cancer, anlegesic, anti-inflammatory, anti-bacterial and including some other activities $\frac{12,13}{2}$. These phytochemicals include flavonoids, phenols and phenolic glycosides, saponins and cyanogenic glycosides, tannins, nitrogen compounds (alkaloids, amines, betalains), terpenoids etc ${ }^{12}$. Antioxidants have importance regarding reducing oxidative stress that could otherwise affect and damage biological molecules $^{14}$. Bioactive components such as flavonoids are natural antioxidant due to its indigenous origin and have strong efficacy to scavenge free radicals $\frac{15}{}$.

Solanum xanthocarpum Schrad. Wendl. is commonly known as yellow-berried nightshade (Syn: Solanum surattens Burm. F; Solanum virginium Linn) that belongs to family solanaceae. It is prickly diffuse bright green perennial herb, somewhat woody at the base. The stem is zig-zag with numerous branches. The berries are globular with green and white stripes when young but yellow when mature and surrounded by the enlarged calyx ${ }^{16}$. In Hindi, it is called Kantkari. Its other names are Choti Katheri, Kateli, Bhatkatiya and Bhachkatiya. It has been reported to occur in Ceylon and Malacca through South-East Asia, Malaya, Australia and Polynessia ${ }^{17}$. It is a wild plant mainly grown in Uttar Pradesh, Uttaranchal, Bihar, Punjab, West Bengal, Assam and other North-Eastern states $\frac{18}{}$. It is a commonly used Ayurvedic medicine for treatment of asthma and bronchitis. Fruit juice of the plant is useful in treatment of sore throats and rheumatism, Decoction of the plant is used in gonorrhea, paste of leaves is applied to relieve pains, seeds act as expectorant in a cough and asthma, roots are expectorant and diuretic and useful in the treatment of catarrhal fever, coughs, asthma and chest pain $\underline{19}$.

This study is designed to evaluate the antioxidant and antiapoptotic efficacy of phytochemically validated SXF extract in primary chondrocytes isolated from rat articular cartilage.

\section{Material and Methods}

\subsection{Materials}

Dulbecco's Modified Eagle Medium/Nutrient Mixture F-12 (DMEM/F-12, 1:1 mixture), 2',7'-dichlorofluorescein diacetate
(DCFH-DA) and Propidium Iodide (PI) were from SigmaAldrich Inc. St. Louis, USA. Fetal Bovine Serum (FBS), sodium pyruvate, Non-Essential Amino Acids (NEAA), sodium bicarbonate, L-glutamine, antibiotic solution (penicillin/ streptomycin), MTT (3-(4,5-dimethylthiazol-2-yl)-2,5-diphenyltetrazolium bromide) dye, were all purchased from Himedia Laboratories Pvt. Ltd. Mumbai, India. Dimethyl Sulfoxide (DMSO), was from Merck Specialities Pvt. Ltd. Mumbai, India. All other reagents were of analytical grades.

\subsection{Collection, Identification and Preparation of Plant Extract}

The fruits of Solanum xanthocarpum were collected from roadsides in Gomti-Nagar and Kursi Road, Lucknow, India in month from September to February. The plant is identified by Prof. S. Lavania, Deparment of Botany, University of Lucknow, Lucknow. A reference of specimen (Voucher No. LWU-20164) has been deposited in the herbarium of Department of Botany, University of Lucknow, Lucknow.

The fresh plant material was collected, washed twice with double distilled water, then shade-dried and turned into powdered. The $95 \%$ ethanolic extract of plant was prepared with the help of Soxhlet apparatus (Borosil Glass Works Limited, India).

\subsection{Phytochemical Screening}

Before evaluating antioxidant and anti-apoptotic activity, the ethanolic extract of SXF was tested for the presence of phytoconstituents by standard biochemical tests for alkaloids, steroids, tannins, saponins and glycosides. The qualitative results are expressed as (+) for the presence and (-) for the absence of phytochemicals.

\subsubsection{Test for Alkaloids}

About $15 \mathrm{mg}$ of SXF extract was taken in a test-tube and stirred with $1 \% \mathrm{HCl}(6 \mathrm{~mL})$ on a water bath for $5 \mathrm{~min}$ and filtered. These filtrates were divided into three equal parts.

- Dragendorff's Test: To the first portion of the filtrate, $1 \mathrm{~mL}$ of Dragendorff's reagent (Potassium bismuth iodide solution) was added. Formation of an orangered precipitate shows the presence of alkaloids.

- Mayer's Test: To the second portion of the filtrate, $1 \mathrm{~mL}$ Mayer's reagent (Potassium mercuric iodide solution) was added. A cream-colored precipitate indicates the presence of alkaloids. 
- Wagner's Test: About 2 g Potassium iodide and 1.27 $\mathrm{g}$ iodine were dissolved in $10 \mathrm{~mL}$ distilled water and diluted to $100 \mathrm{~mL}$ with distilled water. To the third portion of the filtrate, a few drops of prepared solution were added. The appearance of a brown colored precipitate indicates the presence of alkaloids $\frac{20,21}{}$.

\subsubsection{Tests for Steroids and Terpenoids}

- Salkowski Test: About $100 \mathrm{mg}$ of SXF extract was taken in a test-tube. Dissolve the extract in $2 \mathrm{~mL}$ of chloroform $(2 \mathrm{~mL})$ by shaking followed by the addition of $2 \mathrm{~mL}$ concentrated $\mathrm{H}_{2} \mathrm{SO}_{4}$ along the side of the test tube. The appearance of reddish-brown coloration of the interface indicates the presence of terpenoid $\underline{22}$.

- Liebermann-Burchard Test: About $100 \mathrm{mg}$ of extract was shaken with chloroform in a test tube. A few drops of acetic anhydride was added to the test tube and boiled in a water bath, which is rapidly cooled in iced water. A $2 \mathrm{~mL}$ concentrated $\mathrm{H}_{2} \mathrm{SO}_{4}$ was added along the sides of the test tube. Formation of a brown ring at the junction of two layers and turning the upper layer to green indicates the presence of steroids while the formation of deep red color shows the presence of triterpenoids ${ }^{21}$.

\subsubsection{Test for Tannins}

About $0.5 \mathrm{~g}$ of SXF extract was separately stirred with $10 \mathrm{~mL}$ distilled water and filtered. A few drops of 5\% ferric chloride were added to test-tube. Black or blue-green coloration or precipitate indicates the presence of tannins $s^{\underline{23}}$.

\subsubsection{Test for Saponins}

About $5 \mathrm{~g}$ of SXF extract was separately shaken with $10 \mathrm{~mL}$ distilled water in a test tube. The formation of frothing, which remains persist on warming the test-tubes in a water bath for 5 min, indicates the presence of saponins $\underline{23}$.

\subsubsection{Tests for Glycosides}

- Anthraquinone glycoside (Borntrager's Test): To the $1 \mathrm{~mL}$ of SXF extract solution, $1 \mathrm{~mL}$ of $5 \% \mathrm{H}_{2} \mathrm{SO}_{4}$ was added. The mixture was boiled in a water bath for 5 min and then filtered. The filtrate was then shaken with an equal volume of chloroform and kept to stand for 5 min. A $1 \mathrm{~mL}$ of dilute ammonia was shaken with the lower layer of chloroform. There is formation of rose pink to red-color of the ammoniacal layerthat indicatesanthraquinone glycosides $\underline{21}$.

- Cardiac glycoside (Keller-Killiani Test): About $0.5 \mathrm{~g}$ extract was shaken with $5 \mathrm{~mL}$ distilled water. A $2 \mathrm{~mL}$ glacial acetic acid containing a few drops of ferric chloride was added, followed by $1 \mathrm{~mL}$ of $\mathrm{H}_{2} \mathrm{SO}_{4}$ along the side of the test tube. The formation of a brown ring at the interface gives a positive result for cardiac glycoside and a violet ring may appear below the brown ring $\underline{22}$.

\subsubsection{Tests for Flavonoids}

- Shinoda Test: About $1 \mathrm{~g}$ of SXF extract was taken in test-tube and mixed with pieces of magnesium ribbon and concentrated $\mathrm{HCl}$ for few minutes. The appearance of pink color showed the presence of flavonoid.

- Alkaline Reagent Test: About 1 gm of SXF extract was taken in test-tube andmixed with $2 \mathrm{~mL}$ of $2.0 \% \mathrm{NaOH}$. The intense yellow color was produced that became colorless when 2 drops of diluted acid was added to this mixture showed the presence of flavonoids.

\subsubsection{The Culture of Primary Chondrocyte Cells}

The primary chondrocytes were isolated from knees of 2-3 days old rat pups. Isolated cartilage was transferred to phosphate buffer saline (PBS) with $500 \mathrm{U} / \mathrm{mL}$ penicillin and $500 \mu \mathrm{g} / \mathrm{mL}$ streptomycin. Then the cartilages were cut into small pieces, and subjected to digestion with $0.25 \%$ trypsin/EDTA and kept at $37^{\circ} \mathrm{C}, 5 \% \mathrm{CO}_{2}$ incubator for $30 \mathrm{~min}$. The supernatant was centrifuged and resulting pellet was digested twice with $0.2 \%$ type II collagenase for $1 \mathrm{~h}$ each and kept in a $\mathrm{CO}_{2}$ incubator and centrifuged at $1200 \mathrm{rpm}$ for $6 \mathrm{~min}$ to obtain a final cell pellet. Cells were re-suspended in DMEM/F-12 complete culture medium containing $10 \%$ FBS, $100 \mathrm{U} / \mathrm{mL}$ penicillin and $100 \mu \mathrm{g} /$ $\mathrm{mL}$ streptomycin and placed in $50 \mathrm{~mL}$ culture flask ${ }^{24}$.

When the cells reached up to $80-90 \%$ confluency, the cell morphology was observed under phase contrast microscope (Nikon ECLIPSE Ti- S, Japan).

\subsection{MTT Assay for NO Induced Cell Death}

Chondrocytes were suspended in Chondrocyte Growth Medium at a density of $1 \times 10^{4}$ cells/mL and cultured in 96-well plates at $37^{\circ} \mathrm{C}$ in $5 \% \mathrm{CO}_{2}$ for 1 day. After medium change with DMEM/F-12 supplemented with $100 \mathrm{U} / \mathrm{mL}$ penicillin, 100 
$\mu \mathrm{g} / \mathrm{mL}$ streptomycin, and $20 \mu \mathrm{g} / \mathrm{mL}$ gentamicin, chondrocytes were pretreated with $25 \mu \mathrm{M}$ indomathacin (IM) SXF at concentrations $(50,100,250 \mu \mathrm{g} / \mathrm{mL})$ for 1 day. Cell death was induced by treatment of cells with $1.5 \mathrm{mM}$ of SNP for further $24 \mathrm{~h}$. The cell viability was evaluated with a soluble tetrazolium salt MTT [3-(4,5-dimethylthiazole-2-yl)- 2,5-diphenyltetrazorium bromide $]^{25}$.

\subsection{Nuclear Apoptosis Assay}

4,6-Diamidino-2-Phenylindole-2-HCl (DAPI) binds dsDNA that provides a blue fluorescence when viewed under the ultraviolet light. Apoptotic cells are visualized as a small, condensed nucleus. The cells were seeded and treated for $24 \mathrm{~h}$ in 96-well plate in medium containing $10 \%$ FBS and $1 \%$ penicillin/streptomycin solution. Then, the different dose of SXF (50, 100, 250 $\mu \mathrm{g} / \mathrm{mL}$ ) and $25 \mu \mathrm{M}$ IM was added to each well with complete media. After the treatment period, cells were exposed to SNP and further incubated for $24 \mathrm{~h}$. The cells were washed with PBS and fixed in 4\% PFA for $10 \mathrm{~min}$. Subsequently, the cells were permeabilized with permeabilization buffer (3\% PFA and 0.5\% Triton X-100) and stained with DAPI. After the staining images were taken with the fluorescent microscope (Nikon Eclipse Ti-S, Japan) $)^{26}$.

\subsection{Hoechst-Propidium Iodide (PI) Double Staining}

This dye is used to detect normal, apoptotic and dead cells in same culture well. Hoechst is used to stain chromatin of apoptotic cells with fluorescence than normal cells. The PI on the other hand is used to stain chromatin of dead cells. The staining procedure was according manufacturer's protocol (GenScript). The cells were treated with different concentrations of SXF $(50,100,250 \mu \mathrm{g} / \mathrm{mL})$ and $25 \mu \mathrm{M}$ of IM. Further the cells were exposed to SNP for $24 \mathrm{~h}$ in $\mathrm{CO}_{2}$ incubator. A 1 $\mu \mathrm{L}$ of Hoechst 33342/100 $\mu \mathrm{L}$ PBS was loaded in each well and incubated in $\mathrm{CO}_{2}$ incubator for $10 \mathrm{~min}$. After aspiration, a 100 $\mu \mathrm{L}$ of $1 \mathrm{X}$ buffer A mixed with PI was loaded. Plate was then incubated at room temperature in dark for $5 \mathrm{~min}$. Cells were immediately visualized under inverted fluorescence microscope (Nikon, ECLIPSE Ti-Series).

\subsection{DCFH-DA Staining for Reactive Oxygen Species (ROS)}

ROS generation was assessed by 2',7'-dichlorofluorescein diacetate (DCFH-DA) dye. Chondrocyte cells were seeded in black bottom culture plate for $24 \mathrm{~h}$ and incubate the plate at 37 ${ }^{\circ} \mathrm{C}, 5 \% \mathrm{CO}_{2}$ maintained in the $\mathrm{CO}_{2}$ incubator. Cells were then exposed to $20 \mu \mathrm{L}$ ( $10 \mu \mathrm{M}$ stock solution) of $\mathrm{H}_{2} \mathrm{O}_{2}$ for $24 \mathrm{~h}$. Cells were treated with $25 \mu \mathrm{M}$ of IM and SXF at concentrations 50, 100 and $250 \mu \mathrm{g} / \mathrm{mL}$ for $24 \mathrm{~h}$ in triplicate. The cells were further incubated with DCFH-DA dye (stock $10 \mathrm{mM}$ ) for $30 \mathrm{~min}$. The reaction mixture was kept on the shaker for $10 \mathrm{~min}$ at room temperature in dark. Fluorescence intensity was measured with a multi well plate reader (Synergy H1 Hybrid Multi-mode microplate reader, BioTEK) at an excitation wavelength of $528 \mathrm{~nm}$. Photomicrographs of another set of cells seeded in 96 wells plate were taken by fluorescence microscope (Nikon Eclipse Ti-S, Japan) to analyze intracellular fluorescence intensity of ROS production $\underline{26}$.

\section{Results}

\subsection{Phytochemical Screening}

The outcome through phytochemical screening shows that the whole SXF ethanolic extract contains flavonoids, anthraqui-

Table 1. Phytochemical validation of locally collected Solanum xanthocarpum fruit extract through standard biochemical tests

\begin{tabular}{|c|l|c|}
\hline & Phytochemical Test & $\begin{array}{c}\text { Investigation (Present/ } \\
\text { Absent) }\end{array}$ \\
\hline \multirow{2}{*}{1} & Test for Alkaloids & + \\
& (a) Dragendorff's Test & + \\
& (b) Mayer's Test & + \\
& (c) Wagner's Test & \\
\hline
\end{tabular}


Table 1 Continued

\begin{tabular}{|c|l|c|}
\hline $\mathbf{2 .}$ & $\begin{array}{l}\text { Tests for Steroids/terpenoids } \\
\text { (a) Salkowski test } \\
\text { (b) Liebermann-Burchard Test }\end{array}$ & + \\
\hline $\mathbf{3 .}$ & Test for Tannins & + \\
\hline $\mathbf{4 .}$ & Test for Saponins & + \\
\hline & Test for Glycosides & + \\
\hline $\mathbf{5 .}$ & $\begin{array}{l}\text { (a) Anthraquinone Glycoside } \\
\text { (Borntrager's Test) } \\
\text { (b) Cardiac Glycoside (Keller-Killiani } \\
\text { Test) }\end{array}$ & + \\
\hline $\mathbf{6 .}$ & $\begin{array}{l}\text { Test for Flavonoids } \\
\text { (a) Shinoda test } \\
\text { (b) Alkaline reagent test }\end{array}$ \\
\hline
\end{tabular}

Present $=(+)$ and Absence $=(-)$

none glycosides, steroids, alkaloids, terpenoids and tannins. The result has been demonstrated in Table 1 .

\subsection{Inhibition of NO induced cell death}

The production of $\mathrm{NO}$ is an important component that involves in the pathogenesis of OA. We address, whether the given extract reduces the cell death due to induction of NO. The exposure of chondrocytes to the prepared extract before exposure to SNP reduces the cell death significantly $(\mathrm{p}<0.05 \%)$ in dose dependent manner. The increase in viability of cells to approximately must be (50\%), 61\%, 75\% were observed at IM, 50,100 and $250 \mu \mathrm{g} / \mathrm{mL}$ SXF as shown in Figure 1.
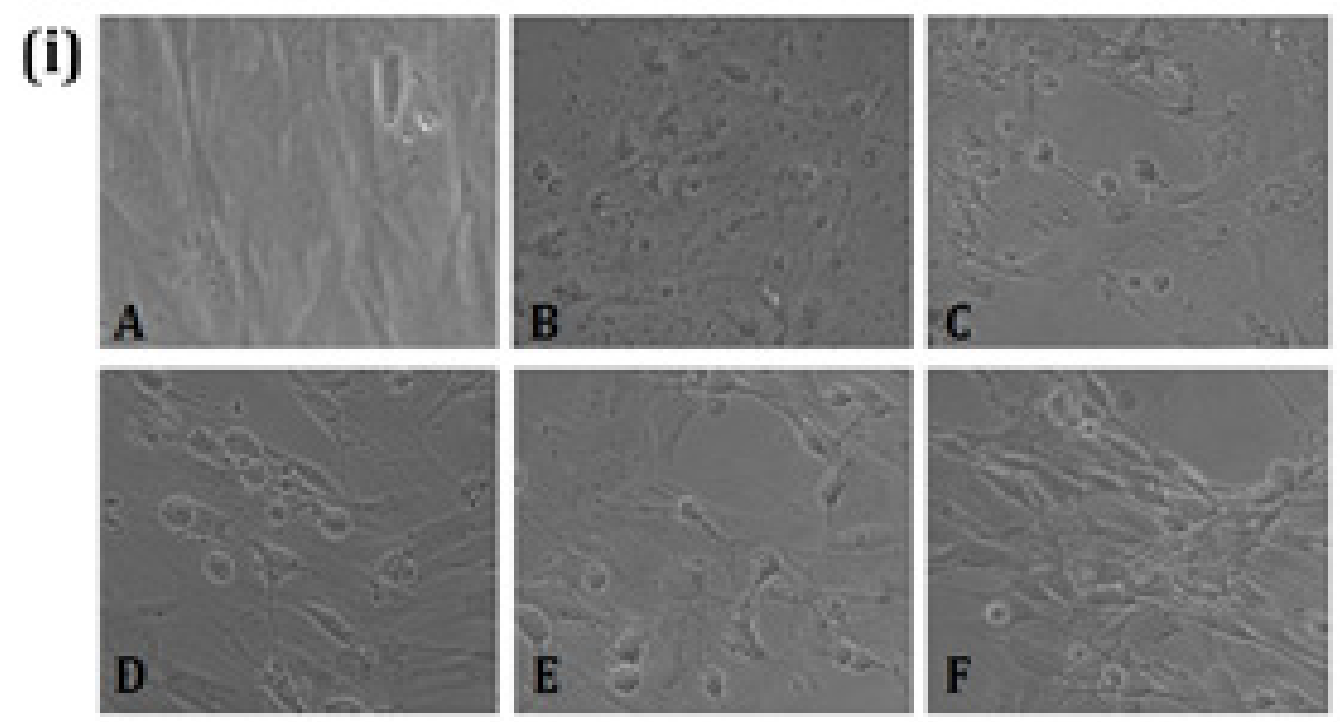


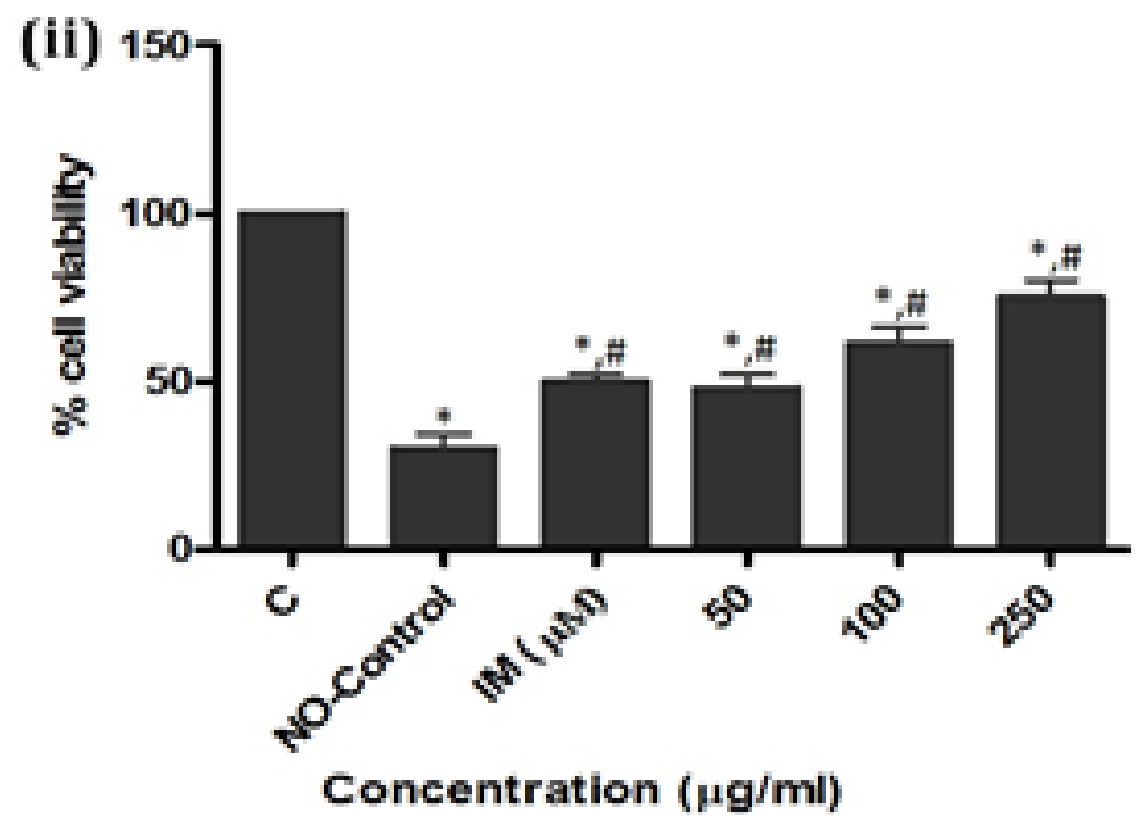

Figure 1. (i) Phase contrast microscopic pictures of chondrocyte at different concentration of SXF extract. (A) Control, (B) NO-Control, (C) IM, (D), (E), (F) at different oncentration of extract $(50,100,250 \mu \mathrm{g} / \mathrm{mL}$ ) (Magnification: 20X; Scale bar: $0.1 \mathrm{~mm}$ ). (ii) Graph represents the effect of SXF on decreased apoptosis and increased \% cell viability in dose dependent manner at different concentrations. Values are obtained from three independent experiments and expressed as mean SEM. ${ }^{\star} \mathrm{P}<0.001$ compared to control and $\# \mathrm{P}<0.05$ compared to $\mathrm{NO}$ induced control (NO-Control). (Magnification $=20 \mathrm{X}$ and scale bar $=0.1 \mathrm{~mm}$ ).

\subsection{Nuclear Apoptosis Assay}

It was observed from photomicrograph (Figure 2), the cells exposed to only SNP (NO-control) shows deep blue fluorescence with condensed nuclei as compared to normal control cells with no fluorescence. The reduction of fluorescence is visualized in IM treated cells and cells treated with $50 \mu \mathrm{g} /$ $\mathrm{mL}$ of SXF compared to $\mathrm{NO}$-control and it further reduces significantly at concentration 100 and $250 \mu \mathrm{g} / \mathrm{mL}$ of SXF. (i)
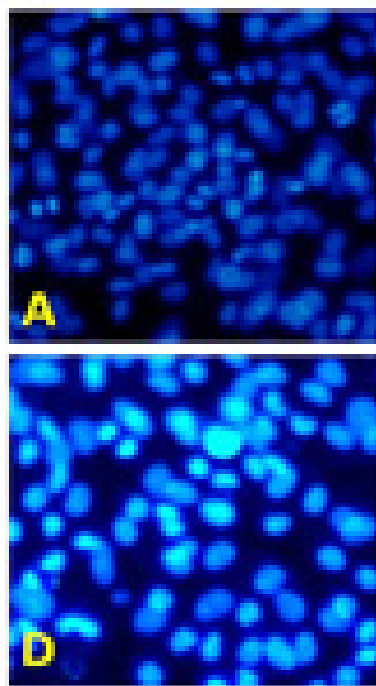
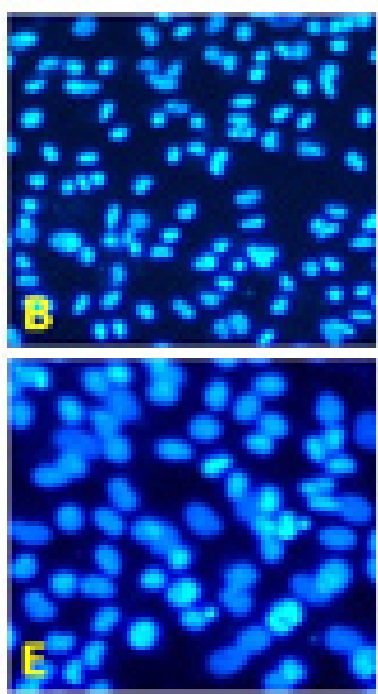

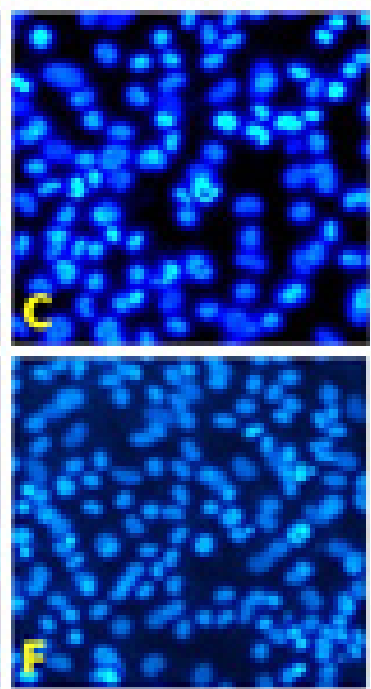




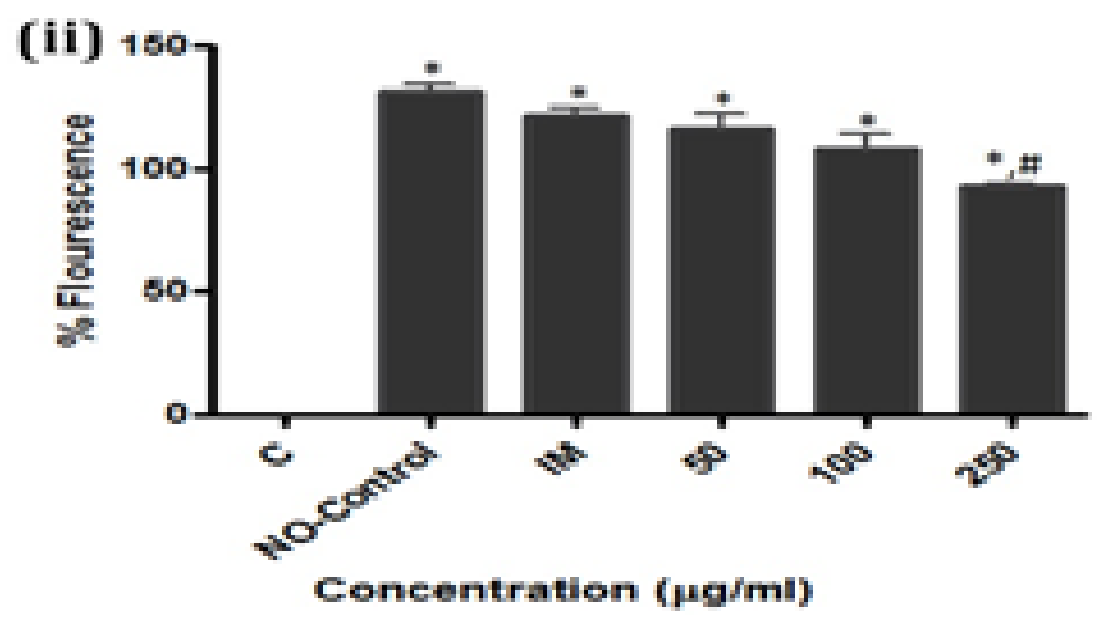

Figure 2. (i) Fluorescence microscopy images showing nuclear condensation in chondrocytes treated with (A) Control, (B) NO-control, (C) IM and (D), (E), (F) different concentrations of $\operatorname{SXF}(50,100,250 \mu \mathrm{g} / \mathrm{mL})$ (Magnification $=20 \mathrm{X}$ and scale bar $=0.1 \mathrm{~mm})$. (ii) Shows graphic representation of $\%$ apoptotic cells respective to their controls. The cells were counted manually under a fluorescence microscope in at least 10 random fields and percent apoptotic cells were calculated as detailed under materials and methods. Values were obtained from three independent experiments and expressed as mean and SEM. ${ }^{\star} \mathrm{P}<0.001$ compared with control and $\# \mathrm{P}<0.05$ compared to $\mathrm{NO}$-control.

Furthermore, about approximately $31 \%$ condensed cells were observed in SNP-control cells compared to control. The numbers of apoptotic and condensed cell reduced to $21.50 \%$, $16.47 \%, 8.18 \%$ and $2.67 \%$ in treated groups IM $25 \mu \mathrm{M}, 50,100$ and $250 \mu \mathrm{g} / \mathrm{mL}$ SXF doses respectively.

\subsection{Hoechst-PI Staining}

Hoechst-PI double staining showed a decrease in the rate of apoptosis with an increase in the concentration of SXF (Figure 3 ). The cells with blue and white fluorescence were undergo-
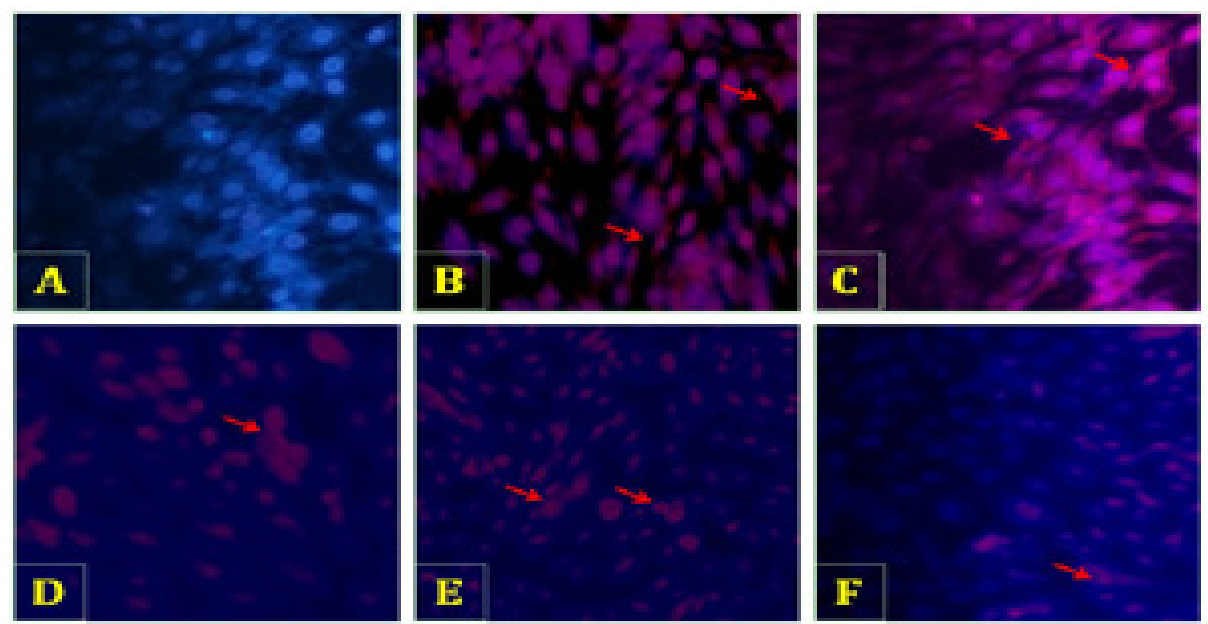

Figure 3. Fluorescence microscopy images showing the cells were treated with SXF extract and $25 \mu \mathrm{M}$ of IM except control group. Pretreated cells were exposed to SNP for $24 \mathrm{~h}$. Arrow marked the apoptotic cells with pink flouresence. (A) Control, (B) NO induced control without any treatment, (C) IM treated cells, (D), (E), (F) treated with 50, 100, $250 \mu \mathrm{g} / \mathrm{mL}$ of SFX extract. (Magnification: 20X; Scale bar: $0.1 \mathrm{~mm}$ ). 
ing apoptosis and cells with pink fluorescence were dead. The NO-control group without any treatment shows maximum fluorescence. The degree of fluorescence was slightly reduced in IM treated group and $50 \mu \mathrm{g} / \mathrm{mL}$ SXF treated cells. However, the fluorescence was significantly reduced at 100 and $250 \mu \mathrm{g} /$ $\mathrm{mL}$ concentration of SXF.

\subsection{Inhibition of ROS Formation}

The exposure of cells to hydrogen peroxide $\left(\mathrm{H}_{2} \mathrm{O}_{2}\right)(10 \mu \mathrm{M}$ stock solution) for $24 \mathrm{~h}$, significantly reduces the number of chondrocytes. The microscopic examination from fluorescence microscope shows that the intensity of fluorescence was decreased with increase in the concentration of dose of SXF
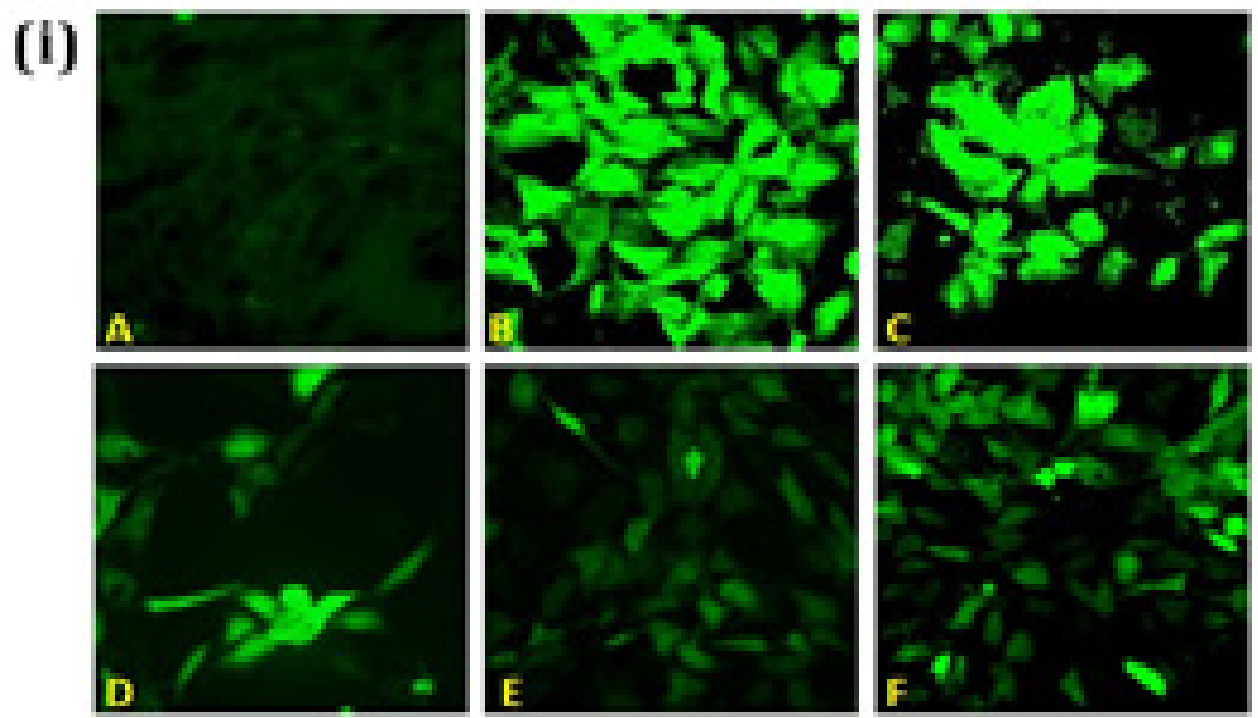

(ii)

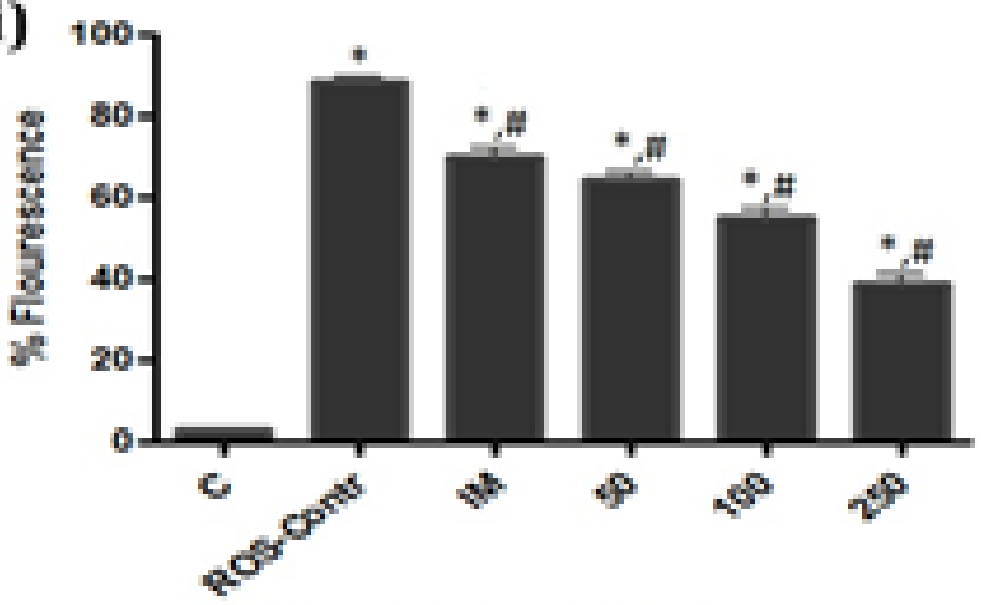

Coneentration (ug/mi)

Figure 4. (i) Photomicrographs of chondrocytes showing antioxidant properties of SXF. Cells exposed to $\mathrm{H}_{2} \mathrm{O}_{2}$ for $24 \mathrm{~h}$ before treatment of IM and SXF extract (Magnification: 20X; Scale bar: 0.1mm). (A) Control, (B) $\mathrm{H}_{2} \mathrm{O}_{2}$ control, (C) IM, (D), (E), (F) at different concentration of extract $(50,100,250 \mu \mathrm{g} / \mathrm{mL})$. (ii) Graph representing percentage of ROS generating cells and calculated as DCF positive cells to total number of cells. Data are represented as mean and SEM. Non-parametric test one way ANOVA: ${ }^{*} \mathrm{P}<0.001$ versus control and $\# \mathrm{P}<0.05$ versus $\mathrm{H}_{2} \mathrm{O}_{2}$ induced $\mathrm{ROS}$ control (ROS-Contr). 
i.e., from 50 to $250 \mu \mathrm{g} / \mathrm{mL}$. The cells, which were exposed to IM shows significant decrease in fluorescence. Quantitative data analysis also demonstrates the significant increase $(\mathrm{p}<0.001)$ in intracellular ROS production when exposed to $10 \mu \mathrm{M} \mathrm{H}_{2} \mathrm{O}_{2}$ is $71.45 \%$. However, when the cells were treated with IM, 50, 100 and $250 \mu \mathrm{g} / \mathrm{mL}$ of SXF, the production of intracellular ROS decreases about $63.41 \%, 64.63 \%, 58.70 \%$ and $39.10 \%$ respectively and thus increases the cell viability as shown in Figure 4.

\section{Discussion}

$\mathrm{OA}$ is a degenerative joint disease with several etiological risk factors. ${ }^{27} \mathrm{Herbal}$ plants produce safety profile compared to the NSAIDs ${ }^{28}$. From the phytochemical screening of SXF extract shows the presence of various phytochemicals viz. flavonoids, anthraquinone glycosides, steroids, alkaloids, terpenoids, tannins and saponins. The phytochemicals detected were known to have certain medicinal importance. Alkaloids derived from plants show an anti-inflammatory property ${ }^{29}$. Phenolic compounds have anti-oxidative, anti-inflammatory, anti-diabetic and anti-carcinogenic properties ${ }^{30}$. Saponin was also known to act as anti-oxidants having anti-inflammatory, weight loss ability and other pharmacological activities ${ }^{31}$. Plant steroids have cardiotonic activity and generally used in herbal medicine and cosmetics ${ }^{32}$. Tannins have astringency property i.e., faster healing up of a wound and mucous membrane ${ }^{33}$. The plant polyphenols have significance, as they are anti-oxidants and free radical scavengers. Polyphenolic compounds have aromatic benzene ring that substitutes hydroxyl radical and its functional derivatives. They can absorb free radicals and can chelate metal ions that catalyze the formation of ROS that promotes lipid peroxidation. Among the polyphenols, flavonoids help to fight against diseases. Its antioxidant potency depends on the molecular structure and position of hydroxyl group including other features in its structure ${ }^{34}$.

There is a reduction in the level of oxidative stress produced due to exposure of cells to $\mathrm{H}_{2} \mathrm{O}_{2}$ pretreated with SXF extract was observed that might be due to the presence of the various antioxidant, anti-inflammatory and anti-apoptotic components in the extract. A study supports our finding that antioxidant present in Sumac leaves induced chondrogenesis through preventing ROS generation ${ }^{35}$. In a study, Zhuang et al., 2016 also describes the inhibitory effect of Angelica sinensis that protect the chondrocyte from $\mathrm{H}_{2} \mathrm{O}_{2}$ induced apoptosis in rat chondrocytes through its anti-inflammatory, antioxidant and anti-apoptotic properties ${ }^{36}$. The anti-apoptotic activities on chondrocytes were observed in cells pretreated with SXF extract for $24 \mathrm{~h}$ and then exposed to SNP-generated NO-induced cell death. There are many studies that provide the correlation between the level of NO production and chondrocyte apoptosis. The effect of SNP over chondrocytes was evaluated with MTT assay for cell viability, nuclear condensation assay and Hoechst-PI staining for apoptosis of cells. In a study, Lee et al., has demonstrated cilostazol protect the chondrocytes from nitric oxide induce apoptosi ${ }^{37}$. It was observed from statistical data and photomicrography that SXF induces proliferation of cells and reduces the apoptosis of chondrocytes in dose dependent manner. The medicinal properties of SXF are due to the presence of various phytochemicals including various polyphenols like flavonoids. These flavonoids possess anti-oxidant properties due to the indigenous origin and strong tendency to scavenge free radicals ${ }^{38}$. Other antioxidants curcumin and quercetin inhibit inflammatory processes and protect chondrocytes ${ }^{39}$. The antioxidant resveratrol protect chondrocytes apoptosis via effects on mitochondrial polarization and ATP production. In a study Beecher et al., 2007 suggested that antioxidant blocks cyclic loading induced chondrocyte death ${ }^{40}$. The data from nuclear condensation suggest that SXF protects chondrocyte from apoptosis. As phytochemicals of SXF contains antioxidants therefore it might be prevent apoptosis.

\section{Conclusion}

The result demonstrates the presence of certain phyto constituents in the ethanolic fruit extract of Solanum xanthocarpum collected from local area of Lucknow, India contains alkaloids, tannins, saponins, flavonoids, steroids and cardiac glycosides. Moreover, the ethanolic extract of SXF shows antioxidant activity by reducing the ROS formation and inhibiting NO-induced cell death in primary chondrocytes.

\section{Acknowledgement}

Author Neelam Shivnath is thankful to ICMR, New Delhi, India for the award of Senior Research Fellowship (No. 45/46/2014/BMS/TRM). The Departmental Equipment Facility, Department of Zoology, University of Lucknow, provided by DST-FIST-PURSE is duly acknowledged. 


\section{References}

1. Little CB, Fosang AJ. Is cartilage matrix breakdown an appropriate therapeutic target in osteoarthritis-insights from studies of aggre can and collagen proteolysis? Curr Drug Targets. 2010; 11(5):561-75. https://doi.org/10.2174/138945010791011956

2. Peat G, McCarney R, Croft P. Knee pain and osteoarthritis in older adults: a review of community burden and current use of primary health care. Ann Rheum Dis. 2001; 60(2):91-7. https://doi. org/10.1136/ard.60.2.91. PMid:11156538 PMCid:PMC1753462

3. Abramson SB, Attur M, Yazici Y. Prospects for disease modification in osteoarthritis. Nat Clin Pract Rheumatol. 2006; 2(6):304. https://doi.org/10.1038/ncprheum0193. PMid:16932709

4. Henrotin YE, Bruckner P, Pujol JP. The role of reactive oxygen species in homeostasis and degradation of cartilage. Osteoarthr Cartil. 2003; 11(10):747-55. https://doi.org/10.1016/S10634584(03)00150-X

5. Hiran TS, Moulton PJ, Hancock JT. Detection of superoxide and NADPH oxidase in porcine articular chondrocytes. Free Radic Biol Med. 1997; 23:736-43. https://doi.org/10.1016/S08915849(97)00054-3

6. Schieber M, Chandel NS. ROS function in redox signaling and oxidative stress. Curr Biol. 2014; 24(10):R453-62. https://doi.org/10.1016/j.cub.2014.03.034. PMid:24845678 PMCid:PMC4055301

7. Henrotin Y, Zheng SX, Labasse AH, Deby GP, Crielaard JM, Reginster JY. Modulation of human chondrocyte metabolism by recombinant interferon. Osteoarthr Cartil. 2000; 8(6):474-82. https://doi.org/10.1053/joca.1999.0323. PMid:11069732

8. Borderie D, Hilliquin P, Hernvann A, Lamarechal H, Kahan A, Menkes CJ, Ekindjian OG. Inhibition of inducible NO synthase by $\mathrm{TH} 2$ cytokines and TGF beta in rheumatoid arthritic synoviocytes: effects on nitrosothiol production. Nitric Oxide. 2002; 6(3):271-82. https://doi.org/10.1006/niox.2001.0418. PMid:12009845

9. Palmer RM, Hickerry MS, Charles IG, Moncada S, Bayliss MT. Induction of nitric oxide synthase in human chondrocytes. Biochem Biophys Res Commun. 1993; 193:398-405. https://doi. org/10.1006/bbrc.1993.1637. PMid:7684906

10. Amin AR, Abramson SB. The role of nitric oxide in articular cartilage breakdown in osteoarthritis. Curr Opin Rheumatol. 1998; 10(3):263-8. https://doi.org/10.1097/00002281199805000-00018

11. Hauser RA. The acceleration of articular cartilage degeneration in osteoarthritis by nonsteroidal anti-inflammatory drugs. Journal of Prolotherapy. 2010; 2(1):305-22.

12. Cai Y, Luo Q, Sun M, Corke H. Antioxidant activity and phenolic compounds of 112 traditional Chinese medicinal plants associated with anticancer. Life Sci. 2004; 74(17):2157-84. https://doi.org/10.1016/j.lfs.2003.09.047. PMid:14969719

13. Miliauskas G, Venskutonis PR, Van Beek TA. Screening of radical scavenging activity of some medicinal and aromatic plant extracts. Food chem. 2004; 85(2):231-7. https://doi. org/10.1016/j.foodchem.2003.05.007
14. Farhat MB, Landoulsi A, Chaouch-Hamada R, Sotomayor JA, Jordán MJ. Characterization and quantification of phenolic compounds and antioxidant properties of Salvia species growing in different habitats. Ind Crops Prod. 2013; 49:904-14. https:// doi.org/10.1016/j.indcrop.2013.06.047

15. Lee KG, Shibamoto T. Antioxidant property of aroma extract isolated from clove buds [Syzygiumaromaticum (L.) Merr. et Perry]. Food Chemistry. 2001; 74(4):443-8. https://doi. org/10.1016/S0308-8146(01)00161-3

16. Ghani A. Medicinal plants of Bangladesh-chemical constituents and uses. Asiatic Society of Bangladesh; 1998.

17. Watt GA. dictionary of the economic products of India. Cambridge University Press; 2014.

18. Singh OM, Singh TP. Phytochemistry of Solanum xanthocarpum: An amazing traditional healer. Journal of Scientific and Industrial Research. 2010 Oct; 69:732-40.

19. Bector NP, Puri. Solanum xanthocarpum (kantakari) in chronic bronchitis, bronchial asthma and non-specific unproductive cough (An experimental and clinical correlation). AS J Assoc Phys India. 1971; 19(10):741.

20. Abdullahi MN, Ilyas N, Ibrahim H. Evaluation of phyto-chemical screening and analgesic activity of aqueous extract of the leaves of Microtrichiaperotitii dc (Asteraceae) in mice using hotplate method. Med Plant Res. 2013; 3:37-43.

21. Joshi A, Bhobe M, Saatarkar A. Phytochemical investigation of the roots of Grewiamicrocos Linn. J Chem Pharm Res. 2013; 5:80-7.

22. Ayoola GA, Coker HB, Adesegun SA, Adepoju-Bello AA, Obaweya K, Ezennia, EC, Atangbayila TO. Phyto-chemical screening and antioxidant activities of some selected medicinal plants used for malaria therapy in southwestern Nigeria. Trop J Pharm Res. 2008; 7:1019-24.

23. Banso A, Adeyemo S. Phytochemical screening and anti- malarial assessment of Abutilon mauritianum, Bacopamonnifera and Daturastramonium. Biokemistri. 2006; 18(1):39-44.

24. Lin JH, Deng LX, Wu ZY, Chen L, Zhang L. Pilose antler polypeptides promote chondrocyte proliferation via the tyrosine kinase signaling pathway. J Occup Med Toxicol. 2011; 6(1): 27. https://doi.org/10.1186/1745-6673-6-27. PMid:22074291 PMCid:PMC3226629

25. T Mosmann. Rapid colorimetric assay for cellular growth and survival: application to proliferation and cytotoxicity assays. J Immunol Methods. 1983; 65(1-2):55-63. https://doi. org/10.1016/0022-1759(83)90303-4

26. Siddiqui S, Ahmad E, Gupta M, Rawat V, Shivnath N, Banerjee M, Arshad M. Cissus quadrangularis Linn exerts dose dependent biphasic effects: osteogenic and anti proliferative, through modulating ROS, cell cycle and Runx2 gene expression in primary rat osteoblasts. Cell proliferation. 2015; 48(4):443-54. https://doi.org/10.1111/cpr.12195. PMid:26079044

27. Janusz MJ, Hookfin EB, Heitmeyer SA, Woessner JF, Freemont AJ, Hoyland JA, Natchus MG. Moderation of iodoacetate-induced experimental osteoarthritis in rats by matrix metalloproteinase inhibitors. Osteoarthr Cartil. 2001; 9(8):751-60. https://doi. org/10.1053/joca.2001.0472. PMid:11795995 
28. Shaikh RU, Pund MM, Gacche RN. Evaluation of antiinflammatory activity of selected medicinal plants used in Indian traditional medication system in vitro as well as in vivo. J Tradit Complement Med. 2016; 6(4): 355-61. https://doi.org/10.1016/j. jtcme.2015.07.001. PMid:27774419 PMCid:PMC5067865

29. Souto AL, Tavares JF, Da Silva MS, Diniz MDFFM, de AthaydeFilho PF, Barbosa Filho JM. Anti-inflammatory activity of alkaloids: an update from 2000 to 2010. Molecules. 2011; 16(10):8515-34. https://doi.org/10.3390/molecules16108515. PMid:21989312

30. Arts IC, Hollman PC. Polyphenols and disease risk in epidemiologic studies. Am J Clin Nutr. 2005; 81(1):317S-25S. https://doi.org/10.1093/ajen/81.1.317S. PMid:15640497

31. Mandal P, Babu SS, Mandal NC. Antimicrobial activity of saponins from Acacia auriculiformis. Fitoterapia. 2005; 76(5):462-5. https://doi.org/10.1016/j.fitote.2005.03.004. PMid:15951137

32. Alexei YB, Joseph IS, Olga VF. Endogenous cardiotonic steroids: Physiology, pharmacology and novel therapeutic targets. Pharmacol Rev. 2009; 61:9-38. https://doi.org/10.1124/ pr.108.000711. PMid:19325075 PMCid:PMC2763610

33. Hisanori A, Kazuyasu F, Osamu Y, Takashi O, Keiji I. Antibacterial action of several tannins against Staphylococcus aureus. J Antimicrob Chemother. 2001; 48:487-91. https://doi. org/10.1093/jac/48.4.487

34. Iqbal E, Salim KA, Lim LB. Phytochemical screening, total phenolics and antioxidant activities of bark and leaf extracts of Goniothalamusvelutinus (Airy Shaw) from Brunei Darussalam.
Journal of King Saud University-Science. 2015; 27(3):224-32. https://doi.org/10.1016/j.jksus.2015.02.003

35. Panico A, Cardile V, Santagati NA, Messina R. Antioxidant and protective effects of sumac leaves on chondrocytes. J Med Plant Res.2009; 3(11):855-861.

36. Zhuang C, Xu NW, Gao GM, Ni S, Miao KS, Li CK, Xie HG. Polysaccharide from Angelica sinensis protects chondrocytes from $\mathrm{H} 2 \mathrm{O} 2$-induced apoptosis through its antioxidant effects in vitro. Int J Biol Macromol. 2016; 87:322-8. https://doi. org/10.1016/j.ijbiomac.2016.02.031. PMid:26893055

37. Lee SW, Song YS, Shin SH, Kim KT, Park YC, Park BS, Lee HJ. Cilostazol protects rat chondrocytes against nitric oxide-induced apoptosis in vitro and prevents cartilage destruction in a rat model of osteoarthritis. Arthritis Rheum. 2008; 58(3):790-800. https://doi.org/10.1002/art.23220. PMid:18311796

38. Lee KG, Shibamoto T. Antioxidant properties of aroma compounds isolated from soybeans and mung beans. J Agric Food Chem. 2000; 48:4290-4293. https://doi.org/10.1021/jf000442u

39. Jackson JK, Higo T, Hunter WL, Burt HM. The antioxidants curcumin and quercetin inhibit inflammatory processes associated with arthritis. Inflamm Res. 2006; 55(4):168-75. https://doi.org/10.1007/s00011-006-0067-z.PMid:16807698

40. Beecher BR., Martin JA, Pedersen DR, Heiner AD, Buckwalter JA. Antioxidants block cyclic loading induced chondrocyte death. The Iowa Orthopaedic Journal. 2007; 27:1. PMid:17907423 PMCid:PMC2150661 